\title{
URGENSI PENDAMPINGAN ORANG TUA PADA PENDIDIKAN ANAK MASA DARURAT COVID-19
}

\author{
Afida Nurrizqi \& Nur Ziadatul Hasanah \\ UIN Sunan Kalijaga Yogyakarta \\ afida2805@gmail.com,nurziadatul@gmail.com
}

\begin{abstract}
This studi to find out how parental assistane is to children during covid 19. The research method used is qualitative reseacrh whice is a study conducted to find out a realiy that occurs in the field. With conditions as they are, not conditions they should be. The results of this study are many paprents who already know about online learning, but there are many obstacles faced by parents including the data quota to acces the internet which is used for online learning. It can be said that online learnig is wasteful in using internet data quota, the limited ability of parents in understand the material provided by the teacher so that it is not clear to the child, the monotonous parental explanation also makes the child bored.
\end{abstract}

Keywords: The Role of Parents, Online Learning, Covid 19

\begin{abstract}
Abstrak : Penelitian ini bertujuan untuk mengetahui bagaimana pendampingan orang tua pada anak selama covid 19. Metode penelitian yang digunakan adalah penelitian kualitatif yaitu adalah suatu peelitian yang dilakukan untuk mengetahui suatu kenyataan yang terjadi di lapangan, dengan kondisi apa adanya, bukan kondisi seharusnya. Hasil dari penelitian ini banyak orang tua yang telah mengetahui mengenai pembelajaran daring, namun banyak kendala yang dihadapi oleh orang tua diantaranya adalah kuota data untuk mengakses internet yang digunakan untuk pembelajaran secara onliine dapat dikatakan bahwa pembelajaran online ini boros dalam pemakaian kuota data internet, keterbatasan kemampuan orang tua dalam memahami materi yang diberikan oleh guru sehingga kurang dapat menjelaskan dengan jelas kepada anak, penjelasan orang tua yang monoton juga membuat anak menjadi jenuh.
\end{abstract}

Kata Kunci; Peran Orang Tua, Pembelajaran Online Covid 19 


\section{PENDAHULUAN}

Pada tahun 2020 sekarang ini, Virus Corona atau severe acute respiratory syndrome coronavirus 2 (SARS-CoV-2) telah menyebar hampir di seluruh dunia termasuk Indonesia, Di Negara kita virus tersebut telah tersebar luas hampir disemua daerah di Indonesia.(Kementrian Pendidikan dan Kebudayaan). Melihat hal ini tentunya virus ini bukan virus biasa, virus yang sangat berbahaya dan dapat dengan mudah menular antara manusis dengan manusia.

Setiap pandemi yang terjadi diberbagai belahan dunia dan periode waktu tertentu selalu menimbulkan korban jiwa yang besar. Oleh karena itu kita harus ekstra waspada dan tidak boleh menganggap remeh. Tentunya hal ini membawa dampak juga bagi dunia pendidikan,berbagai kebijakan di tetapkan oleh mentri pendidikan. surat edaran berbagai kebijakan di tetapkan oleh mentri pendidikan, hingga keluarlah Surat Edaran NOMOR 3 TAHUN 2020 Tentang Pencegahan Coron Virus DISEASE (Covid 19) Pada Satuan Pendidikan.diantara kebijakan tersebut adalah; Aplikasi daring dan televisi untuk pembelajaran, Informasi sumber belajar baik dari televisi dan aplikasi daring secara gratis yang dapat dilaksanakan dalam pembelajaran KBM di rumah.(Kementrian Pendidikan dan Kebudayaan) Dengan demikian guru memantau proses belajar mengajar dari jauh. Kementrian menyediakan berbagai fasilitas untuk pembelajaran secara daring yaitu; Belajar di Rumah Melalui TVRI

Program ini dibuat oleh Kemendikbud untuk jenjang PAUD/sederajad hingga SMA/sederajad. tujuannya adalah untuk penguatan kemampuan literasi dan numeric pada anak. Pada laman Kemendikbud dapat di download secara langsung jadwal dan panduan pembelajaran pada program ini.

Portal Rumah Belajar

Merupakan salah satu portal yang mendukung berbagai komunitas belajar dan menyediakan berbagai bahan untuk proses pembelajaran.

Materi-materi Pengayaan Pendukung Belajar dari Rumah

Penyedia bahan-bahan pembelajaran. (Kementrian Pendidikan dan Kebudayaan)

Dari pemaparan di atas seluruh pembelajaran dilaksanakan di rumah, tentunya semua program-program tersebut akan berjalan dan dapat dilaksaakan dengan bimbingan orang tua. Peran orang tua sangat penting pada masa-masa seperti ini. 
Menurut Ki Hajar Dewantoro peran orang tua sangat pokok tidak bisa digantikan oleh siapapun dalam mendidik anak. Orang tua merupakan mereka yang dapat menerima anak, mencintai, menyayanginya dan mendukungnya. Mereka percaya bahwa anaknya akan menjadi lebih baik dalam kondisi seperti apapun itu. Yang dibutuhkan anak bukanlah kesempurnaan dari orang tua, namun kasih sayang, sebuah syarat yang dapat dipenuhi oleh orang tua manapun tanpa memandang status ekonomi dan pendidikan. (Bukik stiawan;2015).

Tidak hanya tugas seorang guru dalam memberikan bimbingan pada anak, namun juga orang tua meimiliki peran dalam membimbing anak, bahkan memiliki peran yang sangat penting dan menentukan bagi kehidupan anak. Melalui bimbingan ini dapat menetukan nasib dan juga perkembangannya.(Ahmad Susanto;2015) Dengan begitu terlihatkan sangat penting peran orang tua membimbing anak dalam belajar terlebih pada masa pandemi, dimana proses belajar mengajar dilakukan dari rumah. oleh karena itu artikel ini membahas mengenai Urgensi Pendampingan Orang tua terhadap Pendidikan Anak pada Masa Darurat Covid-19.

Berdasarkan hasil observasi yang telah dilaksanakan di SD Pungkuran, Bantul, Yogyakarta pembelajaran dilaksanaka secara online dari rumah, hal ini sangat menuntut komunikasi yang baik antara guru, orang tua dan anak. Perlunya pendampingan belajar yang dilakukan orang tua, karena guru berkomunikasi, memberikan tugas, menerangkan kepada anak melalui orang tua. Oleh karena itu peneliti akan mengfokuskan penelitian tentang Urgensi Pendampingan Orang tua pada Pendidikan Anak Masa Darurat Covid19, yang berlokasi di SD Pungkuran, Bantul, Yogyakarta. Dikarenakan SD ini merupakan sekolah yang sangat merasakaan dampak dari pembelajaran online covid 19, selain itu sekolah ini juga menjalin hubungan komunikasi yang baik dengan wali murid. Sehingga keluh kesah saran dan juga masukan dari para wali murid dapat diterima dengan mudah dan dapat dijadikan catatan atau sebuah perbaikan untuk pembelajaran pada masa covid 19.

\section{METODE PENELITIAN}

Metode penelitian yang digunakan oleh penelitian ini adalah penelitian kualitatif. Pengertian dari penelitian kualitatif adalah suatu peelitian yang dilakukan untuk mengetahui suatu kenyataan yang terjadi di lapangan, dengan kondisi apa adanya, bukan 
kondisi seharusnya, oleh karena itu seseorang yang akan melakukan penelitian kualitatif ini harus memiliki sifat open minded..Dalam pengumpulan data penelitian kualitatif adalah penelitian yang tidak menggunakan angka, namun meggunakan suatu penafsiran untuk memaknai objek. (Mamik;2015). Uji keabsahan data menggunakan Triangulasi adalah teknik pemeriksaan keabsahan data yang memanfaatkan sesuatu yang lain. Di luar data itu untuk keperluan pengecekan atau sebagai pembanding terhadap data itu. (Lexy J melong;2010).

Objek dari penelitian kualitatif adalah segala aspek kehidupan manusia, yaitu kehidupan manusia yang dipengaruhi oleh manusia. Objek ini diteliti secara natural hal yang benar-benar apa adanya.(Mamik;2015). Dalam penelitian ini objeknya adalah pendampingan orang tua pada pembelajaran selama masa covid 19. Bagaimana pemahaman orang tua terhadap pembelajaran daring, bagaimana cara orang tua mendampingi belajar dan juga hambatan yang dihadapinya. Peneltan ini bertempat di .SD Pungkuran, Bantul, Yogyakarya. Subjek dari penelitian ini adalah wali murid kelas 6. Pada penelitian ini peneliti berusaha untuk mendeskripsikan kegiatan pembelajaran yang dilakukan di rumah/ daring pada masa darurat covid 19, langkah-langkah yang ditetapkan oleh pemerintah dan juga peran orang tua dalam mendampingi anak. Dari hasil deskripsi tersebut diadakan analisis data terhadap pendampingan orang tua pada masa covid 19. Kemudikan dikonsruksikan kembali yang akan menghasilkan suatu hasil temuan berupa bagaimana pendampingan yang dilaksanakan orang tua di rumah, manfaat dari belajar online dan cara-cara orang tua menghadapi serta membimbing anaknya dalam proses pembelajaran.

\section{HASIL DAN PEMBAHASAN}

\section{Pendampingan Orang tua terhadap Pendidikan Anak}

Dalam perkembangan seorang anak tidak dapat berkembang sendiri namun ia membutuhkan bantuan dari oranglain, oranglain yang paling utama dan dekat adalah orang tua, peran oragtua sangat pokok dalam perkembagan eksistensi anak. Dengan pendampingan orang tua tersebut diharapkan anak-anak dapat tumbuh menjadi seorang yang memiliki kepribadian baik, harmonis,dan matang sesuai dengan keinginan orang tua. Dalam perkembangan intelektualnya anak dapat mencapai prestasi yang maksimal 
dan memksimalkan potesi yang ada pada dirinya. jadi anak tidak akan menemukan hambatan yang berarti dari pelajaran-pelajaran.

Hal yang sangat dan paling berpengaruh bagi anak adalah orang-orang terdekat yaiu orang tua dan keluarga, diamana hal itu akan sangat mempengaruhi bahkan membentuk pola pikir dan orientasi anak kedepan. Jika peran yang diberilkan orang tua maksimal akan sangat mempengaruhi pula pada pola pikir pendidikan anaknya. Tidak dipungkiri bahwa semua orang tua pasti menginginkan anaknya tumbuh dengan sempurna memiliki kecerdasan, keterampilan, kepandaian dan taat beribadah. Namun pada kenyataanya orang tua saat ini mulai sedikit mengabaikan peranya karena beberapa sebab diantaranya orang tua yang terlalu sibuk. Fokus utama adalah pada pendidikan keluarga dimana orang tua memiliki peran sangat menentukan untuk anak-anaknya yang menjadi unsur paling penting.(Muslim;2020).

Secara umum bahwa pendidikan yang berasal dari keluarga itu bukan kesadaran yang berasal dari ilmu mendidik, namun merupakan sebuah hal yang terjadi secara alamiah suasana yang menciptakan sebuah pendidikan. Hal ini terjadi akibat timbal balik yang saling mempengaruhi antara anak dan orang tua. Oleh karena itu yang paling bertangung jawab atas pendidikan anak adalah orang tua. Baik itu hal itu disadari atau tidak bahwa sebuah tangung jawab namun sudah menjadi fitrah manusia yang telah diberikan oleh Allah SWT. (Tim Dosen PAI;2016). Kehidupan sehari-hari seorang anak dalam bidang pendidikan berawal dari orang tua dan rumah, oleh sebab itu orang tua yang akan memberikan pengaruh,pengajaran dan juga pendidikan. Dalam berinteraksi dengan anak inilah yang merupakan pengaruh, pengajaran dan uga pendidikan orang tua yang diberikan kepada anak. Anak akan meniru dan belajar dari sikap, perilaku orang tua. Disini perlunya kehati-hatian orang tua karena segala tindakan mereka akan diikuti oleh anak.(Harwansyah putra sinaga; 2018)

Berasal dari aspek orang tua yang merupakan guru pertama bagi seorang anak baik orang tua memiliki pendidikan tinggi ataupun rendah. Tentunya semakin tinggi pendidikan orang tua mereka akan semakin sadar bahwa sangat penting peran orang tua sehingga otomatis mereka akan berperilaku baik dengan cara memberikan contoh, perkataan dan perbuatan yang baik didepan anak.(Novrindah, Nina Kurniah \& Yulidesni;2017). 
Dari segi karakter logis seorang anak akan memiliki tingkah laku yang baik dapat bersosialisasi dengan tepat dan tidak mengalami kesulitan yang berarti.(Singgih Gunarso;2010). Untuk mendukung seorang anak menjadi sukses yang perlu dilakukan adalah menanamkan dan membiasakan usaha maksimal dan perjuangan untuk meraih apa yang diinginkan oleh seorang anak. "Fighting spirit" ini adalah istilah semangat dan perjuangan yang tidak mudah untuk menyerah dalam keadaan dan kondisi apapun. mengajarkan pada anak bahwa hidup itu bukan sesuatu yang instan, segala sesuatu yang diinginkan tidak semudah begitu saja didapatkan, namun butuh sebuah perjuangan dan juga usaha yang dilakukan secara maksimal. Kesuksesan di dapatkan dari usaha dan perjuangan yang dilakukan membutuhkan sebuah kesabaran untuk meraihnya. Johannes (2008) dalam hasil penelitiannya menyebutkan bahwa keberhasilan seorang anak adalah adanya figure atau sosok orang tua sejak seorang anak masih kanak-kanak, Peran orang tua yang selalu memberikan dukungan emosional secara teratur akan mempengaruhi daya positif perkembangan anak. Karena adanya orang tua yang selalu memberikan dukungan akan membuat anak merasa ada yang menemani dalam menghadapi kesulitan. Dengan seperti ini anak akan memiliki daya tahan yang baik dalam menghadapi berbaga kesuitan. (Ilhamudin \& Mualifah; 2011)

\section{Pendidikan pada era covid 19}

Setiap pandemi yang terjadi diberbagai belahan dunia dan periode waktu tertentu selalu menimbulkan korban jiwa yang besar. Oleh karena itu kita harus ekstra waspada dan tidak boleh menganggap remeh. Tentunya hal ini membawa dampak juga bagi dunia pendidikan,berbagai kebijakan di tetapkan oleh menteri pendidikan. surat edaran berbagai kebijakan di tetapkan oleh menteri pendidikan, hingga keluarlah Surat Edaran NOMOR 3 TAHUN 2020 Tentang Pencegahan Coron Virus DISEASE (Covid 19) Pada Satuan Pendidikan.diantara kebijakan tersebut adalah; Aplikasi daring dan televisi untuk pembelajaran, Informasi sumber belajar baik dari televisi dan aplikasi daring secara gratis yang dapat dilaksanakan dalam pembelajaran KBM di rumah. (Kementrian Pendidikan dan Kebudayaan).

Memasuki masa pembelajaran pada awal semester genap tahun ajaran dan tahun akademi 2020/2021 Kementrian Pendidikan dan Kebudayaan kembali mengingatkan pada pemerintahah daerah setempat agar berhati-hati dan memperhatikan faktor 
kesehatan dan keselamatan bersama baik itu peserta didik, pendidik, tenaga pendidikan, keluarga maupun masyarakat sebagai prioritas awal dalam proses penyelenggaraan pembelajaran baik itu pembelajaran secara ofline (Tatap muka) maupun online (jarak jauh). (Kementrian Pendidikan dan Kebudayaan Tidak diperkenankan atau tidk diperbolehkan untuk melaksanakan pembelajaran tatap muka pada satuan pendidikan bagi; 1) Satuan pendidikan yang masih belum memenuhi syarat yaitu semua daftar periksa, atau 2) Sebuah satuan pendidikan telah memenuhi semua syarat daftar periksa namun kepala satuan pendidikan memberi keputusan bahwa belum siap jika diadakan pembelajaran secara langsung (tatap muka). 3) Pembelajaran tatap muka belum dapat dilaksanakan pada suatu satuan pendidikan, maka suatu pemerintahan darah sesuai dengan wewenangnya memberikan izin kepada suatu satuan pendidikan untuk melaksanakan pembelajaran tatapmuka diluar lingkungan satuan pendidikan dengan tetap memperhatikan portokol kesehatan. (Keputusan Bersama Menteri Pendidikan dan Kebudayaan, Menteri Agama; 2020)

Pemberian izin yang dilaksanakan oleh pada satuan pendidikan oleh pemerintah daerah kota atau kantor wilayah Kementrian Agama provinsi dan atau kantor Kementrian Agama Kabupaten/ kota dilakukan dengan mempertimbangkan faktorfaktor antara lain; 1) Memperkirakan tingkat penyebaran covid 19 dimasing-masing wilayahnya. 2) Memperhatikan fasilitas kesehatan yang telah siap. 3) Satuan pendidikan dalam menghadapi pembelajaran tatap muka, telah memenuhi persyaratan yang ada. 4) Kemudahan dalam mengakses sumber belajar atau mudah untuk belajar dari rumah 5) Memperhatikan kondisi psikis dari peserta didik 6) Memperhatikan kebutuhan layanan pendidikan bagi peserta didik terutama bagi yang orang tuanya bekerja di luar rumah. 7) Tersedianya akses bagi peserta didik dari dan atau menuju ke satuan pendidikan. 8) Tempat tinggal warga satuan pendidikan 9) mobilitas warga antar provinsi, antar kabupaten/kota, antar kecamatan, dan antar kelurahan/desa 10) Kondisi geografis daerah (Keputusan Bersama Menteri Pendidikan dan Kebudayaan, Menteri Agama; 2020)

\section{PEMBAHASAN}

Dari pemaparan teori di atas maka sangat penting peran dari orang tua untuk pendampingan belajar. Jika sebelum belajar dari rumah (belajar secara ofline) di 
sekolahan saja anak masih membutuhkan arahan dari orang tua, apalagi sekarang ini pembelajaran yang hampir sepenuhnya berada di rumah, oleh karena itu sangat penting pendampingan orang tua pada masa pandemi seperti ini. Sebagian besar dari orang tua telah mengetahui atau memahami secara umum pembelajaran didalam jaringan (daring) melalui internet, hal ini sesuai dengan hasil wawancara yang telah dilaksanakan kepada beberapa orang tua di Sekolah Dasar, jawaban mereka bermacam-macam. Pembelajaran daring adalah proses pembelajaran yang dilaksanakan secara online atau tidak tatap muka, yang dilaksanakan dari rumah (pembelajaran jarak jauh) dengan bantuan atau bimbingan dari seorang guru. selain itu ada juga jawaban yang lain bahwa pembelajaran daring adalah "Pembelajaran daring adalah pembelajaran online yang dilakukan untuk meningkatkan kualitas mutu siswa yaitu dalam hal pengganti belajar mengajar di sekolah, hal ini dilakukan karena adanya pandemi covid-19 maka dari ini kementerian pendidikan serentak melakukan sisem pembelajaran jarak jauh.” Dari hasil wawancara tersebut dapat disimpulkan bahwa sudah banyak wali murid yang memahami pembelajaran daring ini.

Ada berbagai cara orang tua mendampingi anak-anaknya dalam belajar di rumah diantaraya orang tua selalu memantau, mengawasi anaknya ketika proses pembelajaran di rumah, menanyakan kesulitan yang dihadapi anaknya, dan berusaha menjelaskan materi yang dipelajari, hal ini sesuai dengan hasil wawancara dengan wali murid "Memperlihatkan materi yang diberikan guru kepada anak, kemudian bersama-sama mempelajari dan apabila anak tidak paham saya menjelaskan lebih rinci”. Selain itu ada juga orang tua yang belum dapat mendampingi anak belajar seutuhnya karena keterbatasan waktu dimana orang tua sibuk bekerja seharian, sehingga bisa mendampingi anak dalam waktu yang sangat terbatas atau sepulangnya dari bekerja, sabagaimana hasil wawancara yang telah dilakukan peneliti dengan wali murid "Dengan kegiatan rutinitas kerjaan setiap hari jadi mendampinginya ya di sambil kerja,atau gak malam hari baru mendampingi belajar, Saya mendampingi anak tidak sepenuhnya, jadi anak saya belajar sendiri tapi jika anak bertanya saya bantu." Jadi dapat disimpulkan bahwa respon dan tanggapan orang tua terhadap pembelajaran daring ini bermacam-macam.

Demikian pula tidak sedikit dari para wali murid ini yang mengeluh adanya beberapa kendala atau hambatan yang di alami ketika mendampingi anak-anak nya dalam melaksanakan pembelajaran daring, diantaranya adalah sering kehabisan kuota data untuk meng akses internet yang digunakan untuk pembelajaran secara onliine dapat 
dikatakan bahwa pembelajaran online ini boros dalam pemakaian kuota data internet, keterbatasan kemampuan orang tua dalam memahami materi yang diberikan oleh guru sehingga kurang dapat menjelaskan dengan jelas kepada anak, penjelasan orang tua yang monoton juga membuat anak menjadi jenuh. Pada pembelajaran yang dilaksanakan di rumah ini selain kendala-kendala yang dihadapi orang tua pasti juga menimbulkan rasa bosan untuk anak, ada beberapa respon yang dilakukan orang tua ketika anak mulai bosan ada yang dimarahi karena orang tua sudah capek bekerja, namun ada juga orang tua yang terus berusaha mengembalikan semangat dan menjaga fokus anak dengan caracara seperti diajak bercanda dulu untuk menghilangkan kebosanan sejenak baru setelah itu diajak kembali belajar, anak diminta untuk istirahat terlebih dahulu untuk membangun semangatnya kembali, diajak jalan-jalan keliling kebun agar fikiran anak fresh kembali, terus diberikan nasihat dan motivasi agar anak dapat semangat kembali dan bahkan ada dari orang tua yang belum dapat memahami atau mengetahui bagaimana cara membuat anaknya untuk menghilangkan kebosanan.

Pada era Pandemi covid 19 ini pembelajaran dari rumah menimbulkan beberapa perubahan sikap dari anak-anak, diantara perubahan sikap tersebut pun dirasakan oleh wali murid konsentrasi anak mudah teralihkan dengan hal-hal diluar pembelajaran, ketika sedang belajar diluar ada sesuatu langsung keluar dan teralihkan dengan hal-hal kecil, anak menjadi malas-malasan dalam membaca dan belajar seringnya lebih mengandalkan google ketika menjawab soal-soal, anak tidak dapat belajar lama, jika di sekolah ia mampu belajar paling tidak 5-6 jam dirumah paling lama hanya bertahan sekitar 1 jam.

Diantara berbagai kendala-kendala yang dialami tentunya hal ini juga menimbulkan manfaat berdasarkan wawancara dengan saah satu guru di sekolah tersebut, diantaranya terjalinya komunikasi yang intens antara anak dan orang tua di rumah, orang tua bisa memahami kondisi anak ketika belajar dan juga terjalinya kedekatan anak dan orang tua karena sering bersama untuk mengerjakan tugas-tugas dari guru, selain itu terjalin pula komunikasi yang baik antara guru dan walimurit karena guru memantau terus anak-anak yang belajar di rumah melalui orang tuanya.

\section{KESIMPULAN}

Pendampingan orang tua pada pembelajaran selama pandemi ini merupakan hal yang sangat penting. Dimana anak masih sangat perlu untuk diarahkan dan dimotivasi agar 
tetap fokus belajar meskipun kegiatan belajar dilaksanakan dari rimah. Banyak hal yang menjadi kendala orang tua dintaranya sering kehabisan kuota data untuk mengakses internet yang digunakan untuk pembelajaran secara onliine dapat dikatakan bahwa pembelajaran online ini boros dalam pemakaian kuota data internet, keterbatasan kemampuan orang tua dalam memahami materi yang diberikan oleh guru sehingga kurang dapat menjelaskan dengan jelas kepada anak, penjelasan orang tua yang monoton juga membuat anak menjadi jenuh. Namun mekipun demikian banyak hal pula yang dilakukan orang tua untuk menjaga semangat dan fokus anak diantaranya adalah diajak bercanda dulu untuk menghilangkan kebosanan sejenak baru setelah itu diajak kembali belajar, anak diminta untuk istirahat terlebih dahulu untuk membangun semangatnya kembali, diajak jalan-jalan keliling kebun agar fikiran anak fress kembali, terus diberikan nasihat dan motivasi agar anak dapat semangat kembali dan bahkan ada dari orang tua yang belum dapat memahami atau mengetahui bagaimana cara membuat anaknya untuk menghilangkan kebosanan. Namun ada pula manfaat yang dapat dirasa kan dianataranya terjalinya komunikasi yang intens antara anak dan orang tua di rumah, orang tua bisa memahami kondisi anak ketika belajar dan juga terjalinya kedekatan anak dan orang tua karena sering bersama untuk mengerjakan tugas-tugas dari guru, selain itu terjalin pula komunikasi yang baik antara guru dan walimurit karena guru memantau terus anak-anak yang belajar di rumah melalui orang tuanya.

\section{DAFTAR PUSTAKA}

Ahmad Susanto, (2015). Bimbingan dan Konseling di Taman Kanak-kanak, Jakarta;Prenadamedia.

Bukik setiawan,(2015). Anak Bukan Kertas Kosong, Jakarta: Panda Media.

Harwansyah putra sinaga, (2018), Bersahabat dengan Anak Panduan Praktis bagi Orang tua Muslim,Jakarta;Elex Media Komputindo.

Hasil wawancara dari salah seorang wali murid bernama sumarsih pada tanggal 04 desember 2020.

Hasil wawancara dari salah seorang wali murid bernama Anggun permana pada tanggal 04 desember 2020.

Hasil wawancara dengan salah seorang wali murid bernama Adin Fatah pada tanggal 04 desember 2020

Hasil wawancara degan wali murid bernama divi arroyad pada tanggal 04 desember 2020

Hasil wawancara dengan beberapa wali murid bernama sumarsih pada tanggal 04 desember 2020

Hasil Wawancara dengan salah satu guru bernama Ratna pada tanggal 20 Januari 2021. 
Ilhamudin \& Mualifah,(2011). Psikologi anak sukses. memandu anak meraih sukses,

Malang; Universitas Brawijaya Press, 2011

Kementrian Kesehatan Republik Indonesia pada tanggal 25 Mei 2020.

Kementrian pendidikan dan kebudayaan, Kemendikbud siapkan alternative pembelajaran melalui TVRI pada tahun ajaran 2020/2021, Jakarta 28 Desember 2020.

Keputusan Bersama Menteri Pendidikan dan Kebudayaan, Menteri Agama, Menteri Kesehatan, Menteri dalam Negeri Republik Indonesia, Tentang Panduan Penyelenggaraan Pembelajaran pada Tahun 2020/2021 dan Tahun akademik 2020/2021 di masa pandemic coronavirus Disease 2019 Covid 19.

Mamik,(2015). Metodologi Kualitatif, Sidoharjo;Zifatama.

Muslim, (2020) Pengaruh belajar orang tua terhadap prestasi belajar anak dalam mata pelajaran pendidikan agama islam, Yogyakarta; Deepublish.

Novrindah, Nina Kurniah \& Yulidesni;2017). Peran Orang tua dalam Pendidikan Anak Usia Dini Ditinjau dari Latar Belakang Pendidikan, Jurnal Potensia, PGPAUD FKIP UNIB, Vol 2 No 1.

Laman Kementrian Pendidikan dan Kebudayaan.

Lexy J. Moleong, Metode Penelitian Kualitatif, Bandung: Remaja Rosdakarya, 2010.

Singgih Gunarso, (2010). Psikologi Perkembangan,Jakarta;Gunung Mulia.

Tim Dosen PAI, (2016) Penelitian dalam Pendidikan Agama Islam, Yogyakarta; Depublish 